\title{
Ospanova G.T.,
}

senior lecture, doctoral student of Al-Farabi Kazakh National University, Kazakhstan, Almaty, e-mail: maryama140870@gmail.com

\section{ETHNO-CULTURAL VALUES IN MODERN KAZAKH STORIES}

The article deals with the character development of modern Kazakh stories, thematic and ideological direction and various research works. After independence of Kazakhstan scientists pay even more attention to the Kazakh literature. Against the background of globalization, in order to better study Kazakh literature, we need not only to study Kazakh culture well before independence, but also to compare it with the literature of other countries. The novelty and authorship of the Kazakh stories is the description novelty of human destiny analyzed on the basis of M. Magauin, K. Zhumadilov, T. Shapay's works in the context of thematic, style, literary methods after gaining Independence. The object of the study were works, published after independence. The article highlights the combination of postmodernism and literature, which leads to the genre uniformity of the culture of harmony and determines the typological homogeneity of national-genetic or adopted genres. The research results determine the process of literary development and the structural specifics of modern Kazakh literature. Despite of the fact that the article pays great attention to the study of the artistic nature of the work and it is important and valuable that the world authors' views are not only echoes in all Kazakhs, but general heritage of human values. The research revealed that the writers' prose based on strong realistic traditions demonstrates renewal capacities. The literary bases of the stories are formed in the process of complex interaction of different systems. The article makes comprehension on the problems of historical and artistic prose, continuity of cultural and folklore traditions and literature.

Key words: aesthetics, ethnoculture, ethnos, nezavismost, national.

\author{
Оспанова Г.Т., \\ әл-Фараби атындағы Қазақ ұлттық университетінің \\ аға оқытушысы, $\mathrm{PhD}$ докторант, \\ Қазақ,тан, Алматы қ., e-mail: maryama140870@gmail.com \\ Қазіргі қазақ әңгімелеріндегі \\ этномәдени құндымықтар
}

Мақалада қазіргі қазақ әңгімелерінің даму сипаты, тақырыптық-илеялық бағыты мен түрлі ізденіс мәселесі сөз болады. Қазақстан егемендігін алғаннан кейін Қазақ әдебиетіне көп көңіл бөлінді. Жаһандану аясында қазақ әдебиетін тереңірек зерттеу үшін біріншіден тәуелсіздік алғанға дейінгі көркем шығармаларды сыни тұрғыда зерттеу, сонымен қатар әлемдік әдебиетпен салыстыру керек. Тәуелсіздіктен кейінгі қазақ әңгімелерінің тақырыптық, стильдік, көркемдік әдіс тұрғысынан жаңаруы мен авторлық шешім, адам тағдырының бейнелену жаңашылдығы М.Мағауин, Қ. Жұмаділов, Т. Шапай шығармашылығы негізінде талданады. Тәуелсіздік алғаннан кейінгі жылдары жарық көрген шығармалар нысанға алынып, зерттелді. Постмодернизмнің әдебиетпен бірге қатарласа отырып үндесу мәдениеті жанрлық Аүниелердің бірқалыпты болуына әкелетіндігі, ұлттық-генетикалық, және кірме жанрлардың типологиялық біртектілігін анықтайтындығы сараланды. Зерттеу нәтижелері қазіргі қазақ әдебиетінің даму үдерісін, құрылымдық ерекшеліктерін анықтайды. Мақалада шығарманың көркемдік табиғатын зерделеуге үлкен мән берілгеніне қарамастан, шығарма авторының дүниетанымы бүкіл қазаққа ғана емес, жалпы адамзаттық мұра құндылықтарына сай келетіні маңызды және құнды. Жазушылардың өмірлік дәстүрге негізделген шынайы өнері жаңару қабілетін көрсетеАі. Көркем әңгімелер жүйесі өзара әртүрлі күрделі жүйелердің әрекеттесу процесінде қалыптасады. Мақалада тарихи және көркемдік шындық мәселелері мен мәдени, фольклорлық дәстүрлер мен әдебиет сабақтастығы түсіндірілеАі.

Түйін сөздер: эстетика, этномәдениет, этнос, тәуелсіздік, ұлттық. 


\title{
Оспанова Г.Т., старший преподаватель, PhD Аокторант Казахского национального университета им. а^ь-Фараби, Казахстан, г. Алматы, e-mail: maryama140870@gmail.com \\ Этнокумьтурные ценности в современных казахских рассказах
}

\begin{abstract}
В статье рассматриваются характер развития современных казахских рассказов, тематическое и илеологическое направление и различные исследования. После получение независимости Казахстана ученые обращают еще больше внимания на казахскую китературу. На фоне глобализации, чтобы лучше исследовать казахскую литературу, нам нужно не только хорошо изучать казахскую культуру до независимости, но и одновременно сравнивать ее с митературой Аругих стран. Новизна и авторство казахских рассказов после обретения независимости в контексте тематических, стилевых, митературных приемов, новизны описания человеческой судьбы анализируются на основе работ М. Магауина, К. Жумадилова, Т. Шапая. Объектом исследования стали произведения, опубликованные после обретения независимости. В статье выделяется сочетание постмодернизма и литературы, которое приводит к жанровой равномерности культуры гармонии и определяет типологическую однородность национальногенетических или заимствованных жанров. Результаты исследования определяют процесс литературного развития и структурной специфики современной казахской китературы. Несмотря на то, что в статье уделяется большое внимание изучению художественного характера произведения, важно и ценно то, что мировоззрение автора произведения перекликается нетолько со всеми казахскими, но и с общечеловеческими наследиями ценностей. Исследование показало, что проза писателей, опирающаяся на прочные реалистические традиции, демонстрирует способность к обновлению. Художественное целое рассказов формируется в процессе сложного взаимодействия разных систем. В статье осмысляются проблемы исторической и художественной прозы, переемственности культурных, фольклорных традиций и литературы.
\end{abstract}

КАючевые слова: эстетика, этнокультура, этнос, независмость, национальный.

\section{Introduction}

The genres of Kazakh literatureofany stage are developing rapidly. In addition, the genre of the story is a complicated and responsible branch. The writers, by means of short stories, raise not only the great social and society issues, but the issues of the whole national identity in the genre.

"The story is a small, literary work based on storytelling. The genre features of the story are first determined by the method of telling stories, compositions, plot structures, character systems. The story is usually summed up in a compact, narrative case (Erzhanova, 1999: 125). For this reason, the genre of the story requires a great deal of skill and experience from the writer. And the story involves a big issue with its short structure. A great novel includes, the plot, the story, the structural story in itself.

"It's not a five hundred-page novel: it can be five pages. It does not take seven days but one hour to read it. What a pleasure to read an intriguing, interesting story not leaving your eyes from the book after your work, during weekly hours "(Kabdolov, 2010: 214).

And in such a short time only a skillful writer can do his best to influence the reader's senses, feelings of consciousness, create aesthetic opinion, and fulfill the reader's wishes. Fifteen pages in a small volume of work require a great deal of skill to overwhelm a great part of life and lead the reader to a great deal of good manners.

The story can be full of events, but not many characters. Created with a clear theme and idea, the story may be solved in the same channel, which has a real solution. Also, the characters of the story are fully characterized by the appearance of interest conflicts in various events, and it is important to make important conclusions. "The genre of the story requires exceptional literary skills that can be captured by description." (Dictionary of literary terms, 1998: 17)

\section{Experiment}

The genre of conversation has developed it's new era in the course of independence, forming its new direction and channel. The type of new people in the modern society, their actions, and the social structures have led to the formation of a new genre of this small story. We experienced various difficulties in the process of transition to the market relations. Such a radical change has increased the inspiration of many Kazakh writers. Writers Mukhtar Magauin, Sherkhan Murtaza, Kabdesh Zhumadilov, Beksultan 
Nurzhekeev, Duman Ramazan, Askar Altai, Nurgali Oraz, Kuandyk Tumenbay, Talaptan Akhmetzhan, Kuanysh Zhiyenbay and others, stories have created an exceptional literary world of the story genre. Over the past twenty years, after gaining the Independence, the Kazakh writers have continued their tradition in the story genre and in addition to their content, they have created new works of genre, which can reveal the Kazakh identity. The structure of this narration is very complex. Independence has given considerable freedom to choose a topic. It focuses not only on craftsmanship at the national scale of writing, but also the fact that literary tendencies in world literature can be upgraded and developed in Kazakh land. As the President said, we needed the new type of genre which would broaden our ethno-cultural values in our national identity, restores the national code of the Kazakh people, the spiritual consciousness and will, who had recovered from the centuries.

\section{Results and discussion}

It is no doubt, that the Kazakh writers have fulfilled this task. At the same time, we had to expose the forbidden themes and show ethnic values to our country and future generations. First of all, what is ethno-culture and what its meaning is.

The term "Ethno-culture" can be explained by two separate terms. The term "ethnos" originated from Greek as a tribe, a people, one nation separates from other group of people with a common denominator. There are several branches of science associated with the root word ethno. Ethno-culture, ethnogeography, ethnolinguistics, ethnopedagogy, ethno-social, ethno-behavior. Ethno-culture here is an integral part of ethnography. Academician A. Khaidirov said: "Ethno-culture is a natural, social phenomenon characteristic of each ethnic group. Lifestyle, common language, general world outlook, common psychology, etc., we find it all in ethnos' culture. All culture study scholars acknowledge that the main tool for learning all this is a language. According to the purpose of the study to consider the Kazakh people as ethnos, it means not to humiliate them, but to look at its long-way path of development, the only correct and guaranteed way to recognize it as a historical ethnic personality" (Kaidar, 1998: 17)

So, ethno-culture is a broad concept that includes the traditions, customs, everyday life, nature, history, nation's sense of consciousness. It is a very complex concept that covers all national mentality, centuries-old national consciousness, world outlook, traditions, spiritual and material wealth, "says A. Khaidar. And ethno-culture is a source of literature and language, from generation to generation.

We'd like to dwell on, how much the Kazakh writers, in the independent period, learned these ethno-cultural values and how much they have demonstrated at their own level. It is the founder of values, the folklore of our people, musical and poetic, professional and everyday life folklore of Kazakh people.

M. Magauyin is a leading writer of ethnocultural values of our people. One of the keys to art is a character. The majority of M. Magauin's works are national reality. The nature of the heroes gives historical knowledge to the characters, the historical quality of his knowledge (Kulbek, 2013: 600).

Now let's take a look at the story of the writer, "The ant struggle" It is a work that has revealed the qualities of the nation in symbolic ways. Baltabayeva says: This is a story about philosophical thought, "The ant struggle" is not only the worshipto the nature, but also the struggle for life, the continuation of the present, the pledge of the future younger generation and the guarantee for the future - it is a mystery about honoring our land. The author-hero as a literary detail, uses the anthill as a symbolic sign of the country and even the state. Through the injustice, inequality in the life of the smallest insect in the world, the author's style is studied as an unusual form of prose which teaches human being the sense of consciousness. The sacred quality of Kazakh people for many centuries is- the idea of mutual unity and self-esteem, non-recidivism, the idea of the generation's future, - concludes the author.

In this writer's story, the values inherent to our nation are embedded in the concepts. For example, the notion of folklore and our nation, the state, the country, the people and their unity, integrity, and the unity of the country, are given as anthill. By the way, the opinion is given as an assumption. And this approach is a system of ancient Kazakh literature and phenomenon that has taken place in world literature.

"This anthill is a single dynasty or a state. There is a system of special life, unmanageable laws and rules of governance, and, of course, a kind of example, a social structure of some other sort, "begins the story of an insect in the yard of the house. In the mind of our people the ant is a symbol of hard working, selflessness, and workaholic. And we know that we shouldn't destroy anthill in our yards or in the garden, and that we' $\mathrm{d}$ be punished by them. And the writer describes the ants and ant families as in the following way. "Anthill is not only the main 
hub of the state, but also the main place of residence. However, the life of the whole community is much longer - a wider hinge. In the very first days, I realized that the most important landlord in our area is the ancestral dynasty," the author points out his opinion. This passage shows that the main purpose of the story is the unity of the nation. And this is our people's centuries-long tradition. You can see the beautiful brown ant looking for something, even when you go to the bush, climbing in the footstool and grass, even in the leaves of the tree trunks and branches. Here, the writer must think why he is getting a brown color. One of the colors that is closest to our nation, our world view, is a brown color. Depending on this word, our language has a few variable meanings. For example, brown songs, brown voice, brown cold, brown wind, brown back, brown face, brown voice, brown breeze. The brown color is a symbol of a safe and peaceful life, in Kazakh language it reflects warmth, comfort, attractiveness, proximity and color,.

1. The brown color sounds warm to Kazakh, who has world view as brown lamb, brown wind, brown voice, brown creature, even the little child is called with fondle word "brownie". The hero, calls the brown ones as ours. The smallest black ants the foreigner ants - from the outside, clarifies the scientist Baltabayeva (Балтабаева, 2016: 288).

It is known that any literary work is one of the most precious things that keeps people's history and culture at the heart of modern times. Literary work is a way of preserving national values. Professor T. Tebegenov says about this: The literary process the history of spiritual values. The literary work is a reflection of an artistic and aesthetic tradition of the world, reflecting the past, present and future as a whole. "(Tebegenov, 2001: 332)

One of such works is M. Magauin's story "Inter ethnic quarrel". Let's analyze the story of the Kazakh life after our independence.

"Kanat is a strong Kazakh dzigit (young men). The two shoulders are like two mountains, his chest is like a valley and legs are like an oak tree. The fist is like a hammer. Abylai is like a hero of khan's period. They are so attractive, charming. The people can't turn away their eyes from them. Not just from their physical wellness but also from their facial features. Wheat color face, black eyes, sharp nose, moonlighteyelid, beautiful moustache. They do not drink alcohol, and they do not smoke. The only drawback is -illiteracy. It is not a disadvantage. Everybody who has a diploma, now work in the market. He is unemployed. But he has a cow, five sheep, a small piece of land, enough food. "
You are out of service and drunk, "Tekebai said. "You are Kazakh." "Then, your father's mouth!" "You are the one who drags my golden head on the ashes! You are the one who is slaughtering the sacred land of my ancestors! It is you who supported the scoundrel Marat, and let him do what he wanted. "Everybody's scared. They thought he was joking.Then, get it, damned you! Bumped Temir. The first thing we can see is that the concept of a holiness, is the place which belong to our ancestors. The earth was a place of honor and dignity for Kazakh people. All the wealth, beauty, and even the culture and traditions of our country are connected with this place. It is also stored here. We also see the appearance of the Kazakh men, heroes, the character of our national consciousness and mentality. The writer used to describe the events in the society, to describe the shapes, using the linguistic units and characteristics, which were preserved in the minds of our nation, such as chest is like a valley and legs are like an oak tree. The fist is like a hammer. This is a test of the selfishness, which still remains in the Kazakh nation who got independence. Thus, the reasons for the disappearing national character and culture in Kazakh reality are shown in this way: "The national idea comes from our shared destiny. It is the only condition of our survival, whether it is bitter or sweet, today and tomorrow, "said Sh. Eleukenov (Dictionary of literary terms, 1996: 240). It is true, that the literary work is the only way which keeps the nation's culture, literature and century-old history. Therefore, it is well-known that the essence of the work will only increase its value if it is founded on historical reality, realism. This was stated by academician Z. Akhmetov, he concludes that the realities of the poetic nature of the works of the artistic method of realism are based on reality, historical reality, (Argynbaev, 2005: 216)- explains the basis of the literary work.

Let's talk about the stories of K. Zhumadilov. The writer basically focuses on the historical theme. After declaring the sovereignty and independence of the country, the Kazakh literature has also been revived in terms of artistic specifics, poetic style. The individual writers' personal autographs are also determined by the use of language labels in the depiction of the new theme and the phenomena of life. Describing the relationship between the human being and the living world in the midst of life, turned to new direction in literature.

"The death of the eagle", "The Fallen pheasants", "The housekeeper", "The house of God", "One life", "The dwelling world", "The beggar", "Bukarbai's bull", "The last days of the poet " The 
dog market", "The night of the fullmoon, "The pass of Akbura" were written by K. Zhumadilov during independence period.

The writer's story "The pass of Akbura" explicitly illustrates the Kazakh village, the villagers after the independence, the intention of the people to achieve power. Let's look at an example:

"In Sengirtau, there are small tribes/lines of Naiman: Ushik, Kyik, Tuik spread like a black wood, that other people who do not even know. Bazarbek's father's line was Kyik. Being happy, people didn't pay attention to it at all. "For seventy years we obeyed to other one. He is our men" he said. Although they divided into small, different lines but all of them were the children of one grandfather, who is called Koysar. Only seven years before the October Revolution they passed seven generation and began to marry to the girls of the same line. They have sacrificed seven horses and made a feast and celebrated them as usual. Growing is joy, and departing from each other is anxiety. At the feast, Bayserke who was from Oyik, embraced the elder relatives and said, "Oh, my brothers and sisters, is the silk thread of the relative cut off here? How can I be yourmatchmaker from now" he cried bitterly, -so in this passage we can notice the ru/ family relationship which is peculiar to Kazakh nation. The Kazakh nation consists of three zhuz (tribe line). And the ru consists of a number of family members from one ancestry. The names of Ru are the names of our ancestors, great ancestors. The names of the tribal names related to our nation's national identity and ethnicity are part of the Kazakh ethno-culture. It is very important for the Kazakhs to know their ancestors. Because marrying a girl is a matter of great interest for the Kazakhs to keep the blood clean. Also, the Kazakh people paid special attention to the fact that the tribes of the two sides should be different and passed seven generations. H. Argynbayev writes in his book "The Kazakh family" the following: "Some of the most ancient traditions have survived to this day in modern Kazakh families. One of them is to marry keeping a generous exogamic tradition. The preservation of the exogamical order in marriage does not contradict the ideology of a new society.

The Kazakh people did not marry to a girl of the same tribe group if they didn't pass seven generations. But in the north-western and eastern part of the country, if 5-6 generations passed, they allow themselves to marry, but we could say that in the southern and Zhetysu regions it isn't so. That is exactly what is happening today. For example, some tribes of the Greater Zhuz are up 10 to 13 genera- tions keep that tradition. For example, twelve ancestors of jalair tribe, the Alban tribe, sary, konyrat, bozhban, zhetimder don't let their daughters marry to these tribe's men" (Argynbaev, 2005: 216). It is clear from this statement that there is nothing more important than Kazakhs' blood hygiene and generosity. And this trend is always a continuation of the Kazakh marriage. And from this extract we can see that these laws are reflected in the customs and traditions of our nation. Through this story, the writer is able to express his / her personality, character, and attitude to the society through the people of our nation.

The story of the writer "The death of the eagle" also shows a broader picture of national peculiarities. After gaining independence, the Kazakh prose, including the genre of the story, is coming to a new level, and a new breeze to the reader. One of these is the widespread use of the symbolic approach. And in this story, the symbolic nature is represented by the bird world. Symbolic character is one of the most important factors that enhance the artistic appearance of the work. Because the author does not illuminate, disclose his opinion but he inserts symbols, small details, using metaphors, gestures, he offers his views. All the actions that are compatible with human beings combine the nature of life with the bird's life, in many situations, in many things, imagine makes philosophical-social thinking thoroughly about people, and also national cultural values. Now let's look at an example from this story:

"It's a bit of a shock to see that this year, the grassland of this region is not covered. Clearly, there was a change in this field. Something is missing. By the way, where are the four herds? In summer months, there were many sheep herds. Where are the horses, cows? In spring, the field was home to white yurts, which were as white eggs, that did not exist now. Jailaus (pasture) are crushed and nothing is left. This is terrible! In recent years, there may have been a disaster in the region, and there is no trace of it. He did not know that people of that place knew that cattle breeding was unnecessary and that he had left that business". This passage illustrates the essence of the cattle for the nation, it is the symbol of the great wealth of our people. Our cattle breeding stock is a symbol of the country of the Kazakh nation, which is the basis of the cradle of the Kazakh nation, which is related to the life, culture, life of our nation. The writer shows that the wealth of one nation are lost from the bird's sight. It is also known that the Kazakhs were nomadic people. For this reason, the beauty and elegance of the place are great for our nation. Our writers were able to distin- 
guish these features. Yurta is a symbol of the Kazakh people. The indicator of our true national culture. Yurta is a symbol of the tradition of the Kazakh people in their life. The brightest evidence of our nation's vision, centuries-old culture. Because most Kazakh customs and traditions are connected with this yurta. The yurta means, first of all, the wealth of its owner, its place of residence. It had two, three wings, twelve, eighteen, thirty wings. The yurts of the well-known Kazakhs are decorated with large and very rich furniture decorations, as they say. They are called the white horde, the golden horde, the golden fragment.

"The birds also feel that people can divide them as well as into groups as themselves. The eagle, falcon, anchor, hawk, weed, are called "eagles", and their relativesgreyhound, sorghum are considered as "back birds". Eagle is one of the most widely-spoken bird. The word "black" probablymeans 'rootless'. People do not like these birds for their inferiority. They think that their path is severe and that their motives are haram. Black birds does not forgive the dead body. Apparently, warm words can't be heard from the people". From this extract, one of the seven Kazakh treasures is the eagle, the eagle is a holy bird for the Kazakhs. At the same time, the concept of kinship for our nation is very important. The Kazakhs considered all living creatures and nonliving things have their origin of kinship, according to this fact, they can belong to noble family group or not. According to the system, the dynasty is noble, clean, wealthy, cheerful and sympathetically family, but the "black sheep" are not, they are opposite to it.

"This sign of joy was a greeting a king bird. Then, as if to catch sight of it at the moment, the eagle's movements were in full swing. Whoever has noticed before, the golden eagle is even different. The two wings are like a wall, and the feathers have been created very strong. The twilight-ended double legs are like a razor sword. Would not you tell about a steel hinge of the bird as if it divides all over the blue ocean into two? An entirely strong body, which causes the wind to blow in the hunting. The small head, sickle beak... The bald wool scooped up his thighbone legs. The eight-hinged sword are clearly visible. The fierce weapon of the eagle is the spear. "From this fragment of the eagle, we find that the writer widely uses the national-language words. In this way, the peculiarity of eagle has been widely disclosed and described in a special way. In the fragment the author describes the warlike nature of the golden eagle, his strength, his wrath, anger using war weapons. The writer was able to use skillfully the key words which can be basis of our national values set in people's minds in describing Kazakh heroes, their style.

For example, the razor sword, the eight-hinged sword, first of all, is the essence of the Kazakh hero, and secondly, the familiarity of the literary image from the centuries in linguistic units, the third is, the notion familiar to the Kazakh blood and the kinship.

In the story "Dombyra" by T.Shapai, he draws attention to the painful intricacies of the writer in his perception of the world. In this story, the writer says that in life he will not be dead. Especially, he has been able to demonstrate national values, things and historic truths. The title "Dombyra" itself is a surprise for the reader. Because dombyra plays an important role for Kazakhs, that is one of the main concepts in Kazakh language. The dombyra has a centuries-old history of the steppes and rich culture. Moreover, dombyra is a precious sacred property of our nation. This is an indication of the writer that national tradition and consciousness are common. The hero's attitude towards how he missed his dombyra was mystical. The author created two dombyra, the eternal struggle of the old and new, the contradiction between them, the novelty of the new era, the lack of an old one which is close to his heart, how he missed his old dombyra. When the hero asks the master to "make a dombyra", he asks if he needs a dombyra for singer or a cheerful dombyra for kuy/ national music. That's what they both want. The yellow dombyra, as it is, a melodious, sounds good, by playing the sound becomes clearer and brighter as a skillful Kulager. The most amazing thing is that the more the new dombyra gets close, the more old one be forgotten. What does it mean? The symbol of the national values of the Kazakh people. As the new world enters, the more and modernization and globalization become popular, more old one becomes unnecessary. The same is true in spirituality. Sometimes new things are not worth it, but it works with interested people, so when people see new things they are ready to throw away the old one, even though it's precious. The author calls this new dombyra "mute, swan neck dombyra". The old dombyra, as opposed to the new dombyra, was in contrast: "the light of the night", "the empty body made an insignificant, hopeless, crazy voice. There was no sound in dombyra "(Baltabaeva,2016:288).

The main national values in this story are characterized by dombyra, the events associated with it, and the diminished self-esteem of the Kazakh realm and the decline in the new era. In all stories by Tursynzhan Shapai we have a great desire to preserve our national identity. The dombyra in this story is a person, a man, a living soul. It is not 
a thing, but an amazing phenomenon in the image of a person who sees it. This is the success of the writer in this story. The dombyra is a symbol of the national concept and it is a living world, and our national values are a centuries-old witness, the essence of our ancestors and later generations.

\section{Conclusion}

Prose works of the Kazakh society during the historic period of independence attract with their complexity. At the same time, when the artisticideological level and aesthetic power of the artistic works are lessened, the multifaceted and new character of spiritual freedom and creative search becomes noticeable. A new way of describing the various situations of the writer through the unprecedented surrealistic artistic approach is born from the contemporary reader's debate. In the age when the flow of information is predominant, as it is today, the reader can not be overcome by the simple principles and unilateral ideas. The diversity of literary creativity, the penetration of the writer's mental freedom, suggests that today'sKazakh prose also has developed and perfected its individuality. Especially the role of social symbolism in the issue of national idea is the priority. Socio-economic transformations accompanied by the Independence period brought a new impetus to the Kazakh prose. A lot of things are based on national idea. The fate of the land and the country at that time, the theme of "Kazakh cradle - aul (village)" and the national cognition, national spirit, were the peculiarities of the stories' originality. It was originally when the life reality turned into the art reality. It is clear that the Kazakh literature, which had been separated from the Soviet system by the time, was overwhelmed by the beginning. The changes that have taken place in our political and social life, all of which reflect on our national traditions and values, reflect the greatness of our country: the desertion of the village, the truth of the traders, businessmen and ordinary people has been smashed with genuine social insight.

The concept of "wolf", tree-baiterek, "homeland - native people", which has been added to the memory of Kazakh people, has literary significance on every side. Many new historical events, such as the December events and the tragic mark on the fate of the Kazakh people, have been the subject of research for the first time. Also, the main object of the dissertational research is the fate of people who suffered from the polygon and became the victims of policy. That is a distinctive feature of the Kazakh prose. The great news in the Kazakh prose in the period of independence is a religious subject. This is a topic that has been severely restricted in our native literature and wasunable to take its place among literature. Especially in the twentieth century, it was a huge aesthetically damaged. Religion has not only been removed from the state system but has been separated from our cultural identity. Red communist censorship did not play a minor role here. Our literature has been transformed into a red pink body, which has been unconscious and has a single layer of skin.

Summing up, it is the ability to give a true and lasting impression of our national values, from generation to generation, to the future generations and to the future. And it is possible to notice that the creativity of our writers during the independence period, the literary level had the new breath. It is mostly seen in a symbolic way. Also, it is one of the main features of today's Kazakh prose in postmodernism, to avoid being overwhelmed by the imprint of speech, not too much wording, judgment, and not accepting the truth. That is the earliest achievements of Kazakh writers in the years of independence and special ways of bringing national values to the future.

\section{Әдебиеттер}

Ержанова Г. Қазіргі қазақ әңгімесі. Фил. ғылым. канд. дәрежесін алу үшін дайындалған диссертациясы. - Алматы, 1999. - 125 б.

Қабдолов 3. Жанр сыры. - Алматы: Жалын, 1964. - 214 б.

Әдебиеттану терминдер сөздігі. - Алматы: Ана тілі, 1998.

Қайдар Ә. Қазақ тілінің өзекті мәселелері. - Алматы: Ана тілі, 1998.

Құлбек Ергөбек. Қарасөз. Қазақ прозасы туралы ойлар. - Алматы: Ел-шежіре, 2013. - 600 б.

Балтабаева Г.С. Тәуелсіздік кезеңдегі қазақ прозасының көркемдік әлемі. - Алматы: Қаратау КБ ЖШС: Дәстүр, 2016. -288 б.

Тебегенов Т.С. Халық ақындары шығармаларындағы әдебиет пен фольклор дәстүрі. - Алматы: Білім, 2001. - 332 б.

Қазіргі қазақ прозасы және ұлттық идея // Қазақ әдебиеті және мемлекеттік тіл. - 2010. - № 111-12. - Б. 125-133. 
Әдебиеттану терминдерінің сөздігі / Құрастырғандар 3. Ахметов, Т. Шаңбаев. - Алматы: Ана тілі, 1996. - 240 б.

Арғынбаев Х. Қазақтың отбасылық дәстүрлері. - Алматы: Қайнар, 2005. - 216 б.

\section{References}

Argynbaev Kh. (2005) Kazakh family traditions. Almaty: Kainar. 216 b. (In Kazakh)

Baltabayeva G.S.(2016) The literary world of the Kazakh prose in the period of independence. Almaty: Karatau CB LLP: Dastur. 288 b. (In Kazakh)

Dictionary of literary terms. (1998) Almaty: native language. 17 b. (In Kazakh)

Dictionary of literary terms. (1996) Almaty: Ana tili. 240 b. (In Kazakh)

Erzhanova G. Contemporary Kazakh story. (1999) [the Dissertation for getting the degree of phil. Science]. Almaty. 125 b. (In Kazakh)

Kabdolov Z.(2010) Mystery of the genre. Almaty: Zhalyn. 214 b. (In Kazakh)

KhaidarA. (1998) Topical issues of the Kazakh language. Almaty: Ana tili. (In Kazakh)

Kulbek Ergobek. (2013) Looking. Ideas about Kazakh prose. Almaty: El shezhire. 600 b. (In Kazakh)

Modern Kazakh prose and national idea.(2010) [Kazakh literature and state language]. No. 111. 125-133 b. (In Kazakh)

Tebegenov T.S. (2001) The tradition of literature and folklore in folk poets. Almaty: Bilim. 2332 b. (In Kazakh). 